\title{
CONVERSATIONAL IMPLICATURE OF PEANUTS COMIC STRIP BASED ON GRICE'S MAXIM THEORY
}

\author{
Muhartoyo; Sistofa \\ English Department, Faculty of Humanities, BINUS University \\ Jln. Kemanggisan Ilir III No. 45, Kemanggisan-Palmerah, Jakarta Barat 11480 \\ ymuhartoyo@yahoo.com
}

\begin{abstract}
This article discusses about conversational implicature that occurs in Peanuts comic strips. The objectives of this study are to find out the implied meaning in the conversation between Charlie Brown with Lucy van Pelt and Lucy van Pelt with Linus van Pelt to evaluate the existence of maxim flouting and maxim violating in those conversations in relation to the four maxims such as quantity, quality, relation, and manner. Likewise, this study attempts to find out the reason for using conversational implicature in a comic strip. The writers uses a qualitative method with library research concerning to Grice's maxim theory to analyze the conversational implicature. Based on the analysis, it can be concluded that all the comics that comprise 14 comics generate conversational implicature since all the characters breach rules of maxim. The result of this analysis shows that flouting maxim of manner has the highest occurrence of conversational implicature and the least occurrences belong to flouting maxim of relation and violating maxim of quantity. Moreover, the writers concludes that to make a successful communication ideally the speaker and the hearer to cooperate in the conversation by saying explicitly so the hearer can grasp the meaning as the goal of communication is to deliver a message to the hearer.
\end{abstract}

Keywords: Conversational implicature, Grice’s maxim, Non-observance maxim, Peanuts comic strips

\begin{abstract}
ABSTRAK
Artikel ini membahas tentang implikatur percakapan yang terdapat pada komik strip Peanuts. Tujuan penelitian ini adalah untuk mencari makna tersirat dalam percakapan antara Charlie Brown dengan Lucy van Pelt dan Lucy van Pelt dengan Linus van Pelt untuk mengevaluasi keberadaan cemoohan dan pelanggaran maksim dalam percakapan tersebut sehubungan dengan empat maksim: kuantitas, kualitas, hubungan, dan cara. Demikian pula, penelitian ini bertujuan untuk mengetahui alasan penggunaan implikatur percakapan dalam komik strip. Penulis menggunakan metode kualitatif dengan studi pustaka mengenai teori maksim Grice untuk menganalisis implikatur percakapan. Berdasarkan analisis tersebut, dapat disimpulkan bahwa semua komik, yang terdiri dari 14 komik, menghasilkan implikatur percakapan karena semua karakter melanggar kaidah maksim. Hasil analisis ini menunjukkan bahwa cemoohan maksim cara menempati urutan teratas dalam implikatur percakapan dan yang terendah ditempati cemoohan maksim hubungan dan pelanggaran maksim kuantitas. Lebih lanjut, penulis menyimpulkan bahwa untuk membuat komunikasi yang baik idealnya pembicara dan pendengar bekerja sama dalam percakapan dengan berbicara secara eksplisit sehingga pendengar dapat memahami makna ujaran karena tujuan komunikasi adalah untuk menyampaikan pesan kepada pendengar.
\end{abstract}

Kata kunci: Implikatur percakapan, maksim Grice, Non-observance maxim, komik strip Peanuts 


\section{INTRODUCTION}

Communication is a way for people to interact with others, to exchange information or ideas. Sometimes when people talk to their interlocutors they directly do not talk to the point or having implicit meaning, so the interlocutors have to think to understand what have been said. But for some people they usually talk to the core, they directly give the information without having implied meaning, and it is called explicit meaning.

Generally, conversation purpose is to deliver the message by the speakers to their interlocutors. So the interlocutors can understand what the speaker said. Therefore, they must fulfill the requirement of cooperative principles: being relevant, clear and not ambiguous, enough information given, and being truthful.

A successful communication can be determined by those cooperative principles, but sometimes the speakers break those rules by speaking unclearly with less information, so the interlocutors can have different understanding the speaker's intention. This happens as the speakers assume that what they said can be understood by the interlocutors, but the interlocutors do not get what the speaker's meaning. This situation will lead to misunderstanding between them.

There are many ways to elaborate implicative conversation. One of them is through comic. There are many types of interesting comic to be read. One of the most interesting types of comic is comic strip. Peanuts is one of the humorous comic strips which contains implicit meanings. Therefore the writerss are interested in analyzing the conversations in Peanuts comic strips by exploring how a language is applied in that comic that creates humorous effect and therefore gives pleasure for readers.

As far as the writers know there are two similar studies. The first was conducted by Sian in 2007. Her unpublished thesis is entitled "Conversational Implicature: A Study of Garfield's ComicStrips", concentrating on finding answers to two issues: first, to which the categories the utterances can be classified according to speech act; and second, what kind of flouts do the examples of utterances can be noted. The second research was conducted by Rahmawati in 2009. In her unpublished thesis is untitled "The Implicature of Doraemon Comic: Pragmatic Approach", she concentrated on the maxim flouting and the background of maxim flouting in the implicature of Doraemon Comic.

\section{The Purpose of the Study}

In this research, the writers try to find out the implied meaning in the conversation of Charlie Brown with Lucy Van Pelt and Lucy van Pelt with Linus van Pelt and the reason behind the use of implied meaning in the dialogues. In addition, the existence of maxim flouting and maxim violating in those conversations will be evaluated.

In this study the writers analyze the conversational implicature in the conversation of Charlie Brown between Lucy Van Pelt And Charlie Brown with Linus, evaluate the existence of maxim flouting and finds out a reason generating implicature. The main data for this research is Peanuts comic strips taken from http:/gocomics.com/peanuts/. The writers select 14 stories which are classified based on different speakers, 7 stories comprise conversation between Charlie Brown and Lucy Van Pelt, and 7 stories comprise conversation between Lucy van Pelt with Linus van Pelt.

Through this study the writers hope the readers will have a better idea about what is implied meaning that occurs on Peanuts comic strips which generate humorous effect and the implication of those conversations. By evaluating the existences of maxim flouting and maxim violating, the readers 
will have some insights about the difference between maxim flouting and violating so for the readers can understand what are they and can differ what is maxim flouting and maxim violating which based on Grice maxim theory. As for students who are doing their thesis, it is able to be used as a reference for them, especially if they have the same interest or concern.

\section{RESEARCH METHOD}

In this research, the writers uses the qualitative research method. Firstly, the writers collected references by conducting a library research to collect relevant information for this study. The writers also conducted literature retrievals in the Internet concerning the information on the conversational implicature and Grice's maxim theory. Secondly, the writers collected the data from the Internet . The data analyzed in this research were taken from comic strips made by Charles M. Schulz from its website at http:// qocomics.com/peanuts. The writers selected 14 different stories which were classified based on different speakers that is Charlie Brown with Lucy van Pelt and Linus van pelt with Lucy van Pelt. Next, the writers interpreted the conversation. Then, the writers found out the implied meaning in the conversation. Finaly, the writers evaluated which type of the Maxim that is flouted and violated in each story and found its reason.

\section{Theoretical Framework}

In conducting the research, the writers firstly explain the related theories in this section which are presented into two parts. The first part presents the pragmatics theory that includes the Grice's cooperative, maxims, and conversational implicature. The second part is review of non-observance maxims, in order to analyze the 14 comic strips of Peanuts.

\section{Pragmatic}

According to Mey (2001:6), pragmatic is related to Human (users) of the language with their social context. When people communicate in their society they know what their language used and mean. Society influences the language and communicative mean. Therefore, the social aspect of condition influences the language usage in communication. Pragmatic in (Yule, 1993, pp.3-4) as quoted " Pragmatic is the study of speaker meaning" it means that when speaker utters something it must be understood by the hearer so the hearer makes an interpretation of what context includes to whom, where, what and when the conversation takes place. To make a good interpretation the hearer should know what speaker actually want to convey by making inferences. So the hearer perceives what the intended meaning. It looks how the hearer can give response to the speaker's saying. For the example below:

\section{A : I forget my pen. \\ $B$ : Here, use mine.}

In talk exchange, speaker A does not directly ask to speaker B to borrow his pen but speaker B understand speaker's A conveyed meaning by connecting word forgot and pen. Then he does what speaker A expects him to do.

Pragmatic is associated with the relationship between linguistics form (language usage) and the users (human) of those forms and it is to explore people's intended meaning, purpose, assumption, and action. Therefore, it helps people to make sense of what they hear and interpret what others people actually want to convey. 
Pragmatic covers five main areas: deixis, conversational implicature, presupposition, speech acts, and cooperative principle. In this chapter the writers only focuses on conversational implicature and cooperative principle due to this study.

\section{Cooperative Principle}

Grice (1975:54) said that sometimes mislead information between the participants and the speaker in the conversation happens which leads to the disconnection of their remark. This situation shows that they do not cooperate in the conversation. Therefore, cooperation between the participant and the speaker is important so they can reach the purpose of their communication, which leads to rational interaction in communication. Grice (brown; eve; clark; mahon; miller; milroy; p. 25) suggest that there are some basic principles in communication which can make conversation effectively successful and rational.

Jazcolt (2002:210) the cooperative principles of communication can lead to explicit meaning or information in the conversation. As Grice also difined in his book on cooperative principles (Grice, 1975:54) "make your conversational contribution such as is required, at the stage at which it occurs, by the accepted purpose or direction of the talk exchange in which you are engaged".

When we are talking to someone, we (speakers) make an assumption that the hearer can cooperates and knows what we are talking about. Therefore, for successful communication are cooperative principles namely: being relevant, clear and not ambiguous and being truthful are required.

\section{Grice's Maxims}

Grice introduced cooperative principles is to helps the speakers to make the conversation clearer. It is described into four sub-principles which are called 'maxims' (Yule, 1996:37).

\section{Maxim of Quantity}

The rule of maxim of quantity demands the participants of a conversation to give sufficient contribution as required. In other words, the speaker should not give too little or too much information. This maxim can be summarized as follow: 1) Make your contribution as informative as is required (Do not say to little); 2) Do not make your contribution more informative than is required (Do not say too much). We usually assume that people are telling everything we need to know. If they do not say something, we will assume that they simply do not know.

\section{Maxim of Quality}

In order to fulfill the maxim of quality the speaker should make true contribution. It means that he/she should not say what he/she believes to be false and should not say something which lack of evidence. For example, somebody has to say that the capital city of Indonesia is Jakarta not other city, so the rule of this maxim can be briefly described as follows: 1) Do not say what you believe to be false (Do not lie); 2) Do not say that for which you lack adequate evidence (Do not say things you cannot back up).

\section{Maxim of Relation}

This maxim aims the participants of a conversation give a relevance contribution with the topic at that time. The participants should give comments that are only related to the subject and each of them recognizes it.To follow this maxim one should be relevant (do not say things that out of the context). 


\title{
Maxim of Manner
}

The last is maxim of manner, which says the people should be brief and orderly. Moreover, a person who follows this maxim should avoid abscurity and ambiguity.it means they should: avoid abscurity of expression, avoid ambiguity, be brief, be orderly.

These maxims relate to the form of speech being used. One should not use words which will not be understood or say things that you know could be taken multiple ways. You should also not state something in a long, drawn-out way if you could say it in a much simpler manner.

These maxims suggest that the participants should be rational, cooperative and efficient in talk exchange. They have to speak clearly, not ambiguous, relevantly and sincerely, to provide enough information (Levinson,1983, p.102). When in talk exchange speaker are assumed to be cooperative according to those sets of regularities and not to mislead the hearer, so the hearer perceives what the information or meaning.

\author{
A : Is that Natalie? \\ B: Yes. She is \\ (The man directly comes close to that girl and called her name, but he's wrong.) \\ A : Hey ! you said that her name is Natalie \\ $B$ : She is not, but that girl who is wearing blue dress one.
}

In the conversation above both speakers are not cooperative. It is due to the speaker's A assumption of his question "that girl". From the speaker's A perspective, Speaker's B gives less information (quantity) than expected. Speaker B might be expected to provide the information stated in last line. Here, there is mislead information or meaning.

\section{Conversational Implicature}

According to Mey (2001:45) the word 'implicature' is derived from the verb 'to imply', as is its cognate 'implication'. Originally, 'to imply' means 'to fold something into something else' (from the Latin verb plicare 'to fold'); hence, that which is implied is 'folded in', and has to be 'unfolded' in order to be understood. A conversational implicature is, therefore, something which is implied in conversation, that is, something which is left implicit in actual language use. In talk exchange people tend to speak unclearly or implicitly which has implied meaning. For effective conversation the speaker must speak clearly, not ambiguous and straight to the core. Furthermore, Mey (2001:46) cited ' conversational implicature' concerns the way we understand an utterance in conversation in accordance with what we expect to hear'. It means that we (hearer) should interpret what speakers say in order to get the meaning by making inferences. However, sometimes interpreting can be misunderstood by both speakers and hearers just as Leech put it "interpreting utterances is ultimately a matter of guesswork, or hypothesis formation” (1983:30-1).

Jaszczolt (p. 210-11) quoted "implicatures are inferences that are drawn from an utterance and that are perceived by the hearer as being intended meaning”. It means that the hearers make inferences of what speakers said which have intended meaning. Grice also puts it that inferences which are appropriate with presumption of cooperation its called conversational implicature, and the maxims produce inferences which are far from the context of the meaning, they produce implicatures.

Thomas (1995:56) states that sometimes, when people talk to someone or write something to, they conveyed what they mean, but usually they are implicit. As they try to convey something which is far from what their words mean. Hence, the hearers should infer what speaker's utterance or words. As Grice puts it in his theory that he tries to explain to a hearer that should get what is actually meant by what is said which from the level of stated meaning into implied meaning. 


\section{Non-observance of Maxims}

Based on Thomas (p. 64), there are many cases and reasons for the participants fail to observe the maxims, such as they do not speak clearly or ambiguous, and they deliberately speak untruth. According to Grice (1975:49) in conversation the participants may fail to observe the maxim. In this research however, the writers only focuses on analyzing the flouting or violating of the maxims that causes humorous effect. The types of non-observances will be explained below.

\section{Flouting a Maxim}

In talk exchange, people usually talk something which they want to convey unclearly something which is beyond what is actually said. They tend to convey something which has an implicit meaning. Therefore, the speakers want the hearer to interpret perceived meaning. As Thomas (1975, p. 65) emphasized A flout occurs when a speaker intentionally do not observe the maxims, there is implied meaning of what is said. A speaker should be considered as flouting maxims when they want the hearers to understand what mention exactly, there must be an implicit meaning for the hearer.

Here some examples of flouting of each maxim.

Maxim of quantity

A: well how do I look?

B: your hat is nice (B gives too little information; B does not say that the t-shirt and jeans do not look nice. However, B knows that A will understand that he actually want to say that A does not look nice)

Maxim of quality

A: May I go along with you?

B: Sure, I must be late (the fact is B objected to invite A)

Maxim of relation

A: How is your life?

B: It's has been raining a lot lately, hasn't it? (B signals to anotuher person that he wants to move away from the topic of the conversation has been raised)

Maxim of manner

A: Let's get the kids something

$B$ : Ok, but not I-C-E-C-R-E-A-M (spelling out) (the fact is her kids get cough, she does not tell her husband directly)

\section{Violating Maxim}

Cutting (2008:38) violating of maxim is when a speaker does not want the hearer's to know his real intention. A speakers does not want the hearer to know what the truth and he or she just want the hearer to understand his utterances or words. As Thomas (1995:73) explained "the speakers intentionally generate a misleading implicature". Cutting also defines 'maxim of violation is unostentatiously, quietly deceiving'. Which the speakers intentionally give less information, they say something insincerely, irrelevantly and ambiguously. So the hearer gets wrong assumption that the speakers and the hearers are cooperating. For examples:

A man: Does your dog bite?

A woman: No.

(The man reaches down to pet the dog, then the dog bites the man's hand)

A man: Ouch! You said your dog does not bite! 
A woman: That is not my dog. The woman know that the man was talking about the dog in front of her and not her dog at home, yet she intentionally did not give enough information, for reasons best known to herself.

\section{Infringing maxim}

Infringing occurs if "The speaker has an imperfect command of the language ( a young child or a foreign learner), because the speaker's performance is impaired in some way ( nervousness, drunkenness, excitement), because of some cognitive impairment, or simply because the speaker constitutionally incapable of speaking clearly, to the point” (Thomas, 1996:74). It means that the speaker is uncooperative in the conversation, due to the speaker's incapability of the language or his emotional condition.

\section{Opt Out}

Sometimes, there are many ways or reasons for the speaker to be uncooperative in conversation one of them is such showing unwillingness to cooperate the maxim requires which is called by Opting out. Usually it happens in daily public life, when the speaker cannot observe the maxim due to for any kinds of reasons such for legal or ethical reasons by normally answering what is expected. At the point, the speaker is just showing uncooperative and avoids making implicature (Thomas, 1995:74).

Grice (1957:49) defines Opt out when a speaker obviously indicates his or her unwillingness to cooperate in the way the maxim requires. For an example: sorry! I could not answer it, as I do not have much time.

\section{RESULTS AND DISCUSSION}

As previously stated this stuy aims to analyze conversational implicature, evaluate the existence of Maxim of flouting and Maxim of violating that occurs in the Peanuts comic strip and finds a reason generating implicature. Hence, first, the writers provide the description of Peanuts characters which are subjects to the analysis in this paper and a brief history of Peanuts comic strips. Then, the writers elaborate the process of colleting and selecting the data under the heading of data collection. Finally, the writers analyze the conversational implicature based on Grice's maxim theory covering the four maxims such as: quantity, quality, manner, and relation are discussed. In addition, maxim flouting and maxim violating are included in the analysis.

\section{About Peanuts Comic}

A peanuts comic strip is composed by Charles M. Schulz. It was first published in 1950 before that the name was L'il Folks L'il Folks until it changed to Peanuts and it appeared on seven newspapers. Peanuts tells stories about daily life of children in which each story ends with a joke. In outline, Peanuts comic was different from other comics of its era, the different lied on deep charaters of the comic and Schulz could connect the characters to the readers. By providing funny, interesting story, and adorable characters, Peanuts has been successful in featuring its style or characterization which makes the readers feel happy to read Peanuts comic. The "Peanuts' comic strip appeared in almost 1,480 U.S. and 175 foreign newspapers with 90,000,000 readers. In 1984 Peanuts was qualified for a place in the Guinness Book of World Records after being sold to the 2,000th newspaper. 
The last Peanuts comic appeared on January 3, 2000, after Schulz announced himself for his retirement, due to a stroke which weakened his memory and motivation to draw. Schulz died on February 12, 2000. The last Peanuts comic featured Charlie Brown who was kicking a football and he missed it. Meanwhile Lucy was sitting at her psychiatrist's stand, and Snoopy was typing Schulz's letter. "Dear Friends," Schulz writes, "I have been fortunate to draw Charlie Brown and his friends for almost 50 years. It has been the fulfillment of my childhood ambition. Unfortunately, I am no longer able to maintain the schedule demanded by a daily comic strip. My family does not wish Peanuts to be continued by anyone else; therefore I am announcing my retirement. I have been grateful over the years for the loyalty of our editors and the wonderful support and love expressed to me by fans of the comic strip. Charlie Brown, Snoopy, Linus, Lucy..How can I ever forget them.”. As we all witness, Peanuts has become the most successful comic strips in the newspaper history ever. personal.psu.edu/cyp5015/Assign6.html\#history

\section{Charlie Brown}

Charlie Brown is drawn with only a small curl of hair at the front of his head, and a little at the back. He almost always wears black shorts and a short-sleeved shirt, usually yellow, with a black zigzag stripe around the middle. He is the lovable character in the story. He has a younger sister named Sally Brown and has a dog named Snoopy which he really cares. He is the captain of baseball team and his willingness is to win a baseball match. In fact, his team doesn't have enough ability to play but he is still patient and he keeps practicing with them.

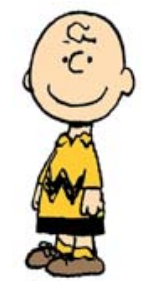

Figure 1 Charlie Brown

\section{Lucy van Pelt}

Lucy van Pelt is a talkative Linus's big sister. Actually she wants to help Linus to change his bad habit, but she does it in the wrong way by mocking him. At first, she likes Charlie Brown but in the recent scripts, she turns to belittle him even while they are practicing baseball, although she is worse than him.

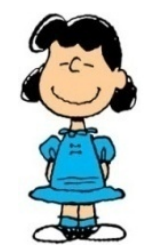

Figure 2 Lucy van Pelt

\section{Linus van Pelt}

Linus van Pelt is Lucy's younger brother and Charlie Brown's best friend. The source of his frustration is Lucy, who always belittles him, particularly over his security blanket. Linus' bad habit 
which makes his sister really hates him is bringing his blanket and sucking his thumb. He brings his blanket everywhere he goes since it gives security to him but in the recent scripts he seldom brings his blanket in his appearance.

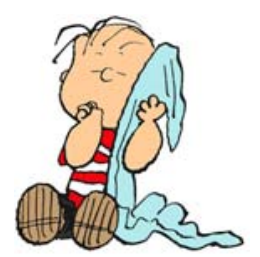

Figure 3 Linus van Pelt

Source: peanuts.com/characters/

\section{Data Collection}

The data analyzed in this paper are Peanuts comic strips which were taken from www.gocomics.com/peanuts. Peanuts is a daily comic strips. The writers chooses the data based on the characters which are Lucy van pelt, Charlie brown and Linus van pelt, as they are the main characters. Then, the writers chooses 14 different stories that comprise of 7 conversations between Charlie Brown with Lucy van pelt and 7 conversations between Lucy Van pelt with Linus van pelt. Four comics were downloaded in July, three comics were taken in August, one comic were taken in September and six comics were taken in October. The data which have been chosen are then analyzed to find out the conversational implicature and the existence of Flouting and Violating of Grice's four maxims which are quantity, quality, manner, and relation.

\section{The Analysis of Conversational Implicature Based on Grice's Maxim}

According to Grice in talk exchange sometimes people say something unclearly, ambiguously and not directly to the core, which will result in implied meaning. Therefore, the hearers should get what is actually meant by the speakers they are talking with. In other words, the hearers have to understand unstated meaning to implied meaning. In this context Peanuts comic strips are suitable data to be analysed in order to find out conversational implicature. It seems the characters in these comic strips intentionally breach the rules of maxim to generate humorous effect. Hence, the writers is interested in finding out the implied meaning and evaluates the existence of maxim flouting and maxim violating in these comic strips.

\section{Flouting Maxim}

As mentioned in the previous theory overview, maxim flouting is defined when a speaker intentionally and obviously breaks the rules of maxim by saying something which is beyond what actually said which results in an implicit meaning. In this case the speaker wants a hearer to interpret the meaning or what was said.

\section{Flouting Maxim of Quantity}

Flouting maxim of quantity happens when a speaker intentionally gives too much or less information than it requires. This situation will generate the conversational implicature. The four comic strips below show this kind of maxim flouting. 


\section{Comic 1}
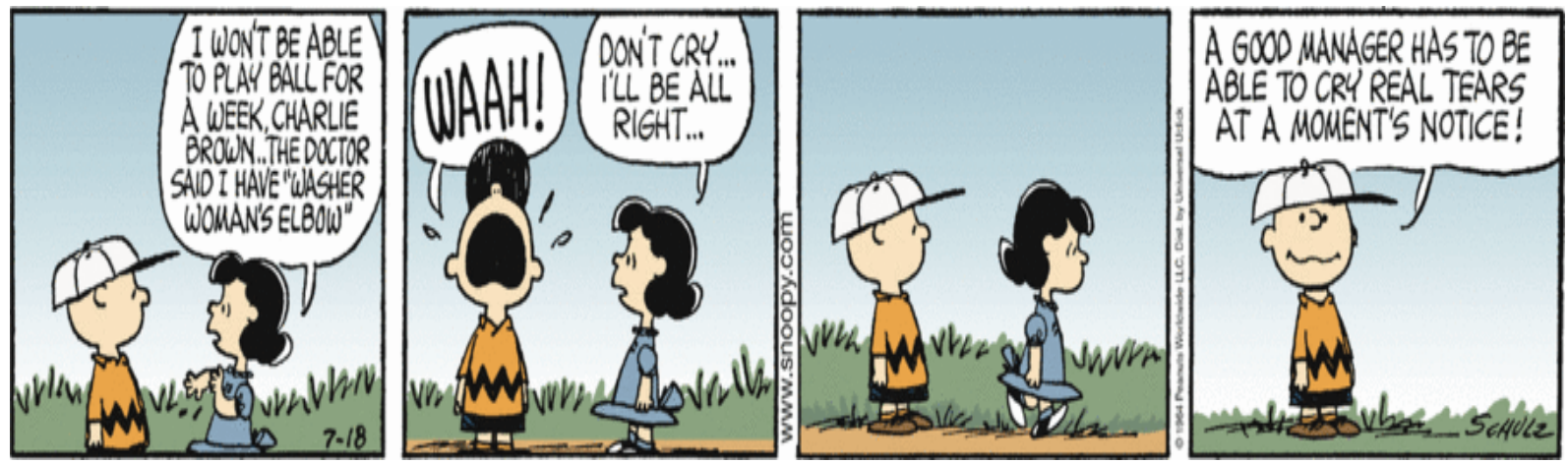

Figure 4 Comic 1

Retrieved on July 18, 2011

Lucy made an excuse implying that her elbow was weak. When she uttered the words, Charlie said nothing but he was crying out loud or wailing "WAAH!”. Lucy assumed that Charlie felt sorry about her health condition. Therefore she asssured him that she would be fine and would continue participating the game. As soon as Lucy left, Charlie smirked and said that that was his way of persuading her to join in the game by just using one, but effective, response in form of the loud cry. Charlie succeeded to make Lucy believed him as Lucy assumed that Chalie's immediate loud cry showed his care for her. On the other hand, Charlie did not want to speak too much to respond to Lucy's excuse. He was simply wailing "waah" and It proved to be an effective response. It can be seen from Lucy’s appreciation by saying "Don’t cry I’ll be alright.”

\section{Comic 2}
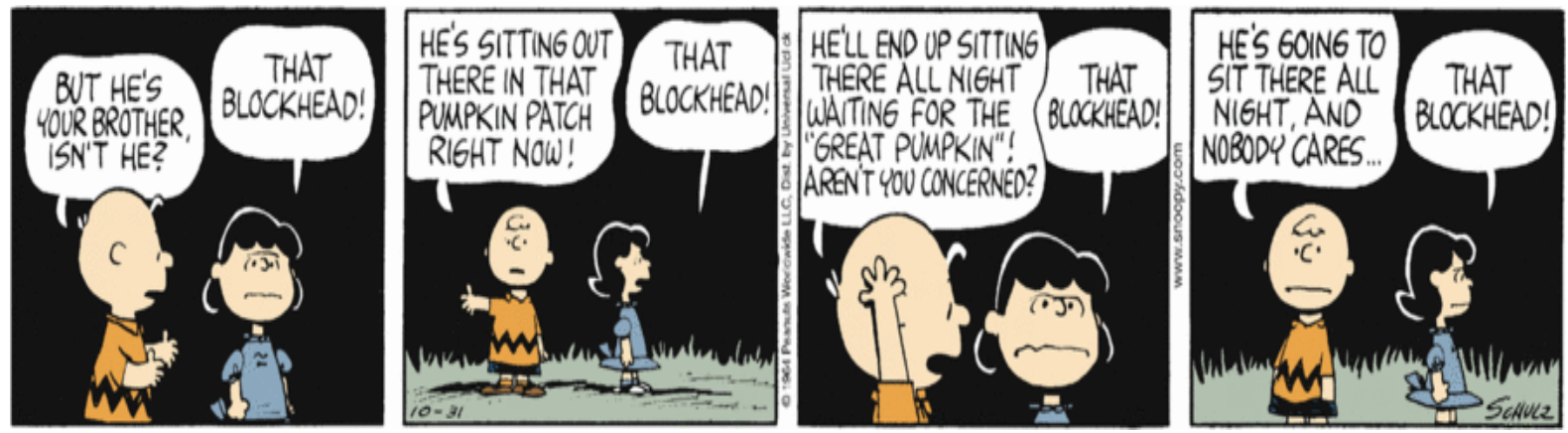

Figure 5 Comic 2

Retrieved on October 31, 2011

Feeling worried, Charlie wanted to tell Lucy that Linus who is Lucy's brother, were sitting on pumpkin path all alone. Surprisingly Lucy did not show any sympathy to what Linus was doing. She simply gave a short sarcastic statement by saying "that blockhead". Lucy's sarcastic statement implied that she did not care of his brother Linus. Her statement also implied that she considered what her brother was doing was a stupid thing. Having received unsympathetic response from Lucy, Charlie kept trying to get Lucy's sympathy for her brother by saying "He 'll end up sitting there all night waiting for 'the Great Pumpkin'! Aren’t you concerned?”. Charlie also insisted by saying "He‘s going to sit there all night, and nobody cares...”. Despite Charli's persistent attempt to attract Lucy's attention to her brother, Lucy just kept saying "that blockhead" and walked away. Charlie felt dismay of what Lucy had done and said to her brother. 


\section{Comic 3}
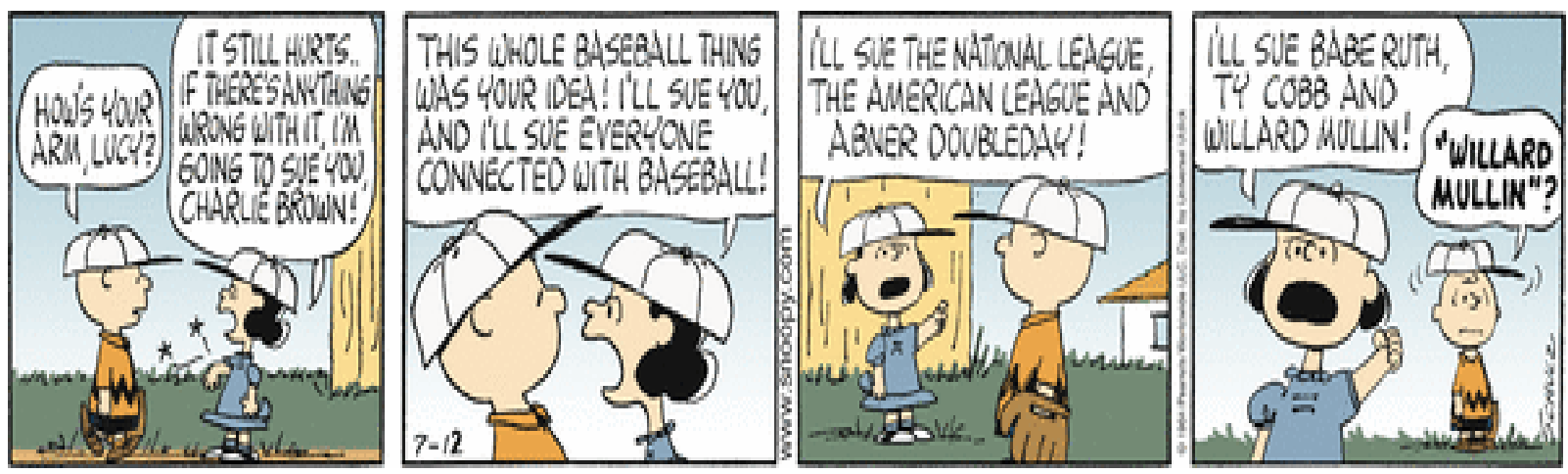

Figure 6 Comic 3

Retrieved on July 12, 2011

In the conversation above Lucy expressed her anger to Charlie Brown who had asked her to join the baseball game. She thought that Charlie had to be responsible for her arm injuries due to the baseball game. She threatened to sue Charlie if her arm injury would go wrong. To show that she is really upset with her arm injury, she kept talking and insisted that Charlie Brown should take the blame for the injury. Even she was bluffing that she would sue anyone or organization related with Baseball game. The funny thing is when Lucy mentioned some famous baseball player's names, and she also mentioned Willard Mullin name. Charlie wondered why Lucy included William Mullin together with the several famous baseball players. As we may all know that Williard Mullin is not a baseball player, but he is only an American sport cartoonist. All of the Lucy's remarks implied that Lucy is the person who likes to have others to blame. She does not want to accept the reality that the injury may also be caused by her own fault.

\section{Comic 4}
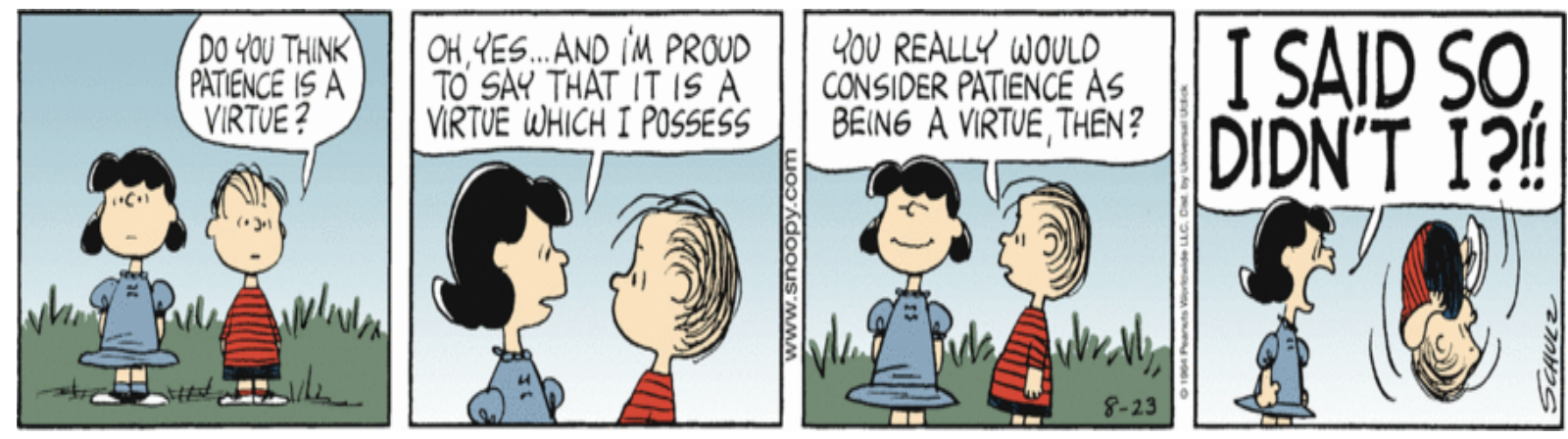

Figure 7 Comic 4

Retrieved on August 23, 2011

What a funny dialogue! In this dialogue, Linus asked a question to Lucy what her notion about patience, then, Lucy answered "Oh yes.... and I'm proud to say that it is a virtue which I possess". This statement implied that she considered herself as a patient person. Linus did not believe what he had heard from Lucy, as she usually behaved impatiently and did not show any sympathy to him. Therefore, Linus repeated his question to make sure himself that Lucy is a patient person. He did not need to wait too long to get Lucy's anger who shouted at him “I said so, didn't I?!!”. Lucy's answer implied that she was not a patient person. 


\section{Flouting Maxim of Relation}

This kind of maxim flouting happens when a speaker intentionally breaks maxim by making a response which is obviously irrelevant to the topic which they are talking about, or she or he intentionally diverts the topic. This maxim flouting can be seen at the conversation below.

\section{Comic 5}
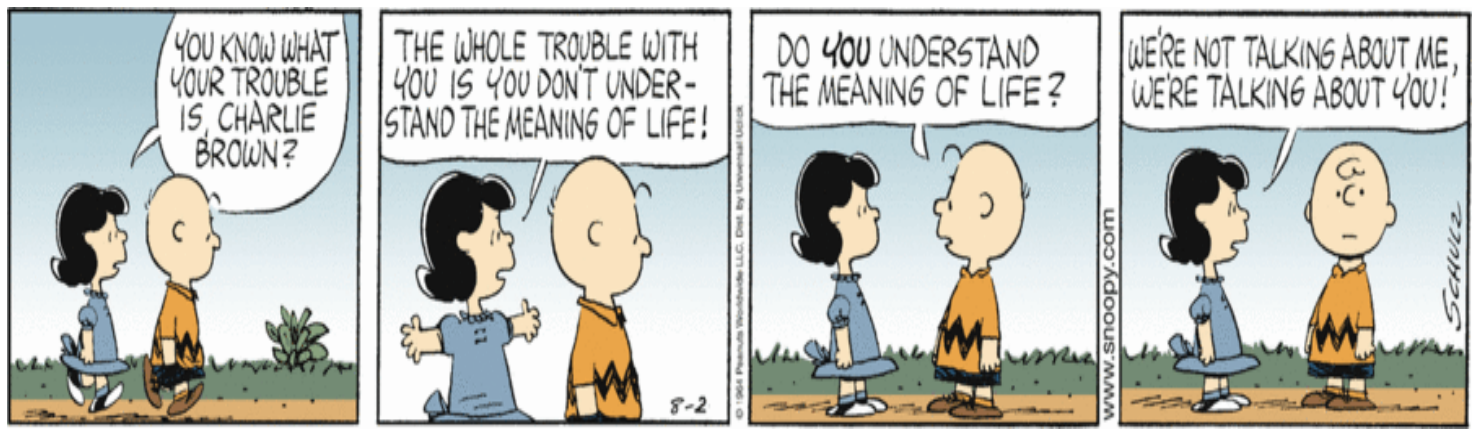

Figure 8 Comic 5

Retrieved, August 2, 2011

The conversation above shows that Lucy offered her advisce to Charlie who felt very gloomy and desperate. According to Lucy, Charlie's problem was caused by his ignorance of the meaning of life. Lucy confidently advised Charlie by saying "The whole trouble with you is you don't understand the meaning of life." Having heard Lucy's advice, Charlie asked a similar question to Lucy "Do you understand the meaning of life?" This question implied that Charlie felt insulted by Lucy's advice and was curious to know what Lucy's notion about life was. Furthermore, this question implied that Charlie did not consider Lucy as a wise person who was in a proper position to give advice to him. Feeling surprised with a reciprocal question from Charlie, Lucy who did not expect such a question diplomatically replied the question by saying "we're not talking about me, we're talking about you”. In other words, Lucy diverted the question or the topic as she did not have any idea about the meaning of life, and she hoped that Charlie could define it first. It can be concluded that either Charlie or Lucy does not know the meaning of life, both of them divert the topic.

\section{Flouting Maxim of Quality}

Flouting maxim of quality happens when a speaker obviously says something which is untrue and he or she lacks of evidence. It can be said that it is contrary with the truth. The two comic strips below can be included in this maxim flouting category:

\section{Comic 6}
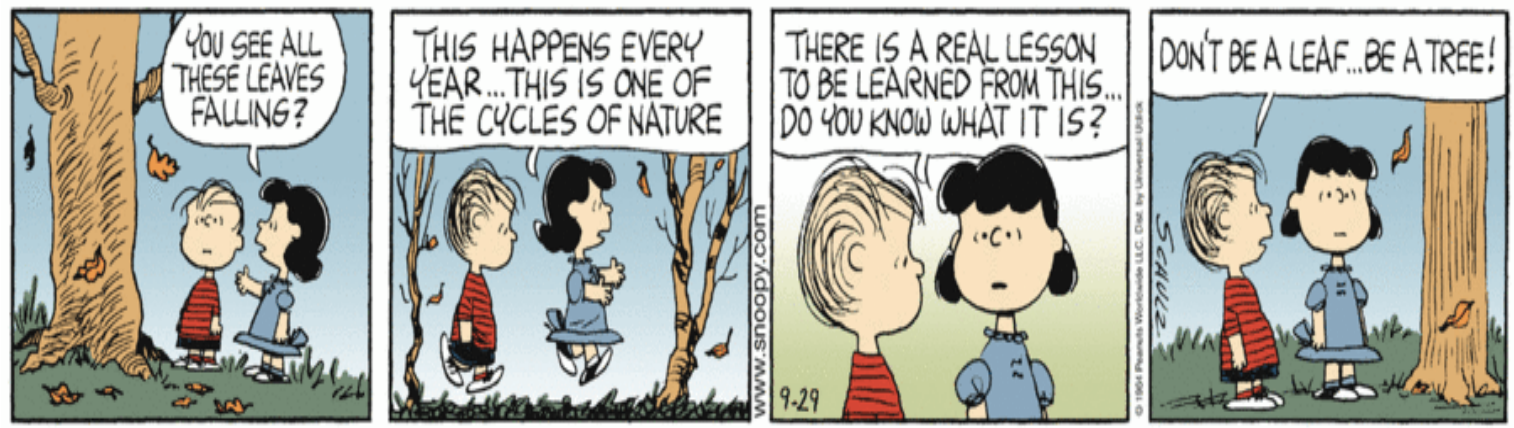

Figure 9 Comic 6

Retrieved on September 29, 2011 
From the conversation above it can be conluded that both Linus and Lucy were not in the same wavelength. Lucy defined the natural life cycle in the world by using leaves and trees as metaphor, whereas Linus grasped Lucy's metaphoric statement literally, the real leaves and trees. Therefore, a misperception occurred. Linus failed to understand the implied meaning conveyed by Lucy, however this makes the dialogue humorous. What Lucy actually wanted to convey in her metaphoric statement was that Linus could learn that there is nothing eternal in the world, a new life or thing will replace the old stuff so in this life we have to make use our time effectively and usefully as our time is limited, but Linus ignorantly answered Lucy's question by using literal meaning which is obviously out of context. Instead of covering up his ignorance by giving out of context answer, Linus should say ‘no, I don’t know’ and ask Lucy about it.

\section{Comic 7}
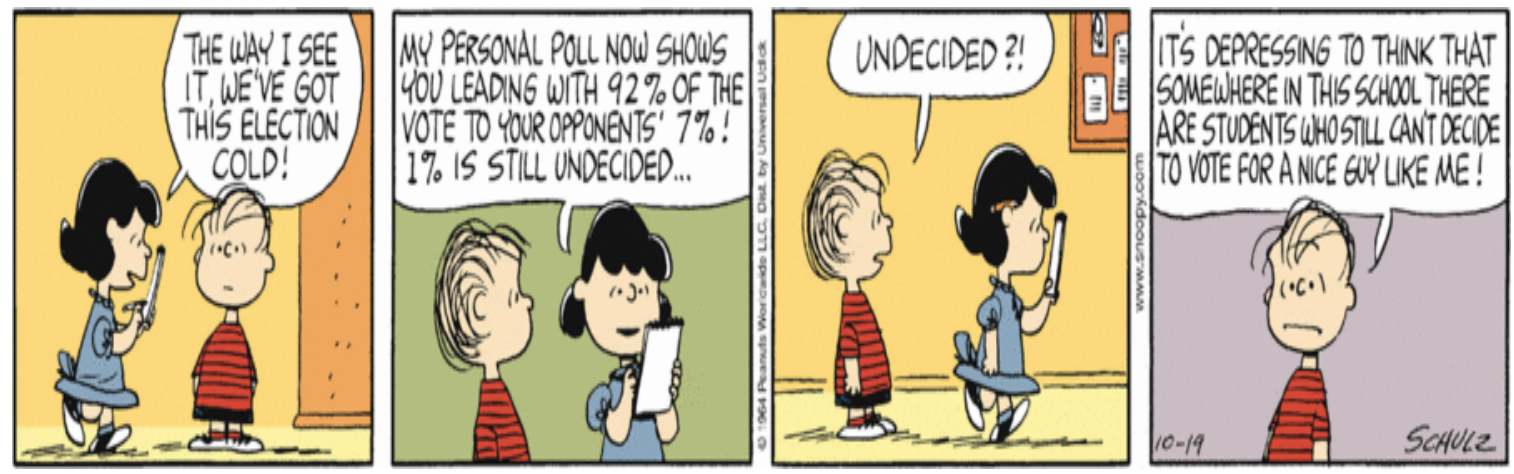

Figure 10 Comic 7

Retrieved on October 19, 2011

In this dialogue Lucy showed her personal poll result to Linus while she was explaining that the election was going to be cold. It was because according to her poll Linus was temporarily leading the vote with $92 \%$ and his rival only gained $7 \%$. Lucy added that the remaining $1 \%$ was still floating or had not been determined yet. Knowing that there was $1 \%$ undecided vote, Linus gave a boisterous statement "It is depressing to think that somewhere in this school there are students who still can't decide to vote for a nice guy like me!" What Linus said here might not be true, he was not supposed to give a boisterous comment like that.

\section{Flouting Maxim of Manner}

This kind of maxim flouting takes place when a speaker intentionally says something ambiguously and obscurely. Let's say it is how the way of speaker says something. Then, it generates an implicature, as in the conversation below.

\section{Comic 8}
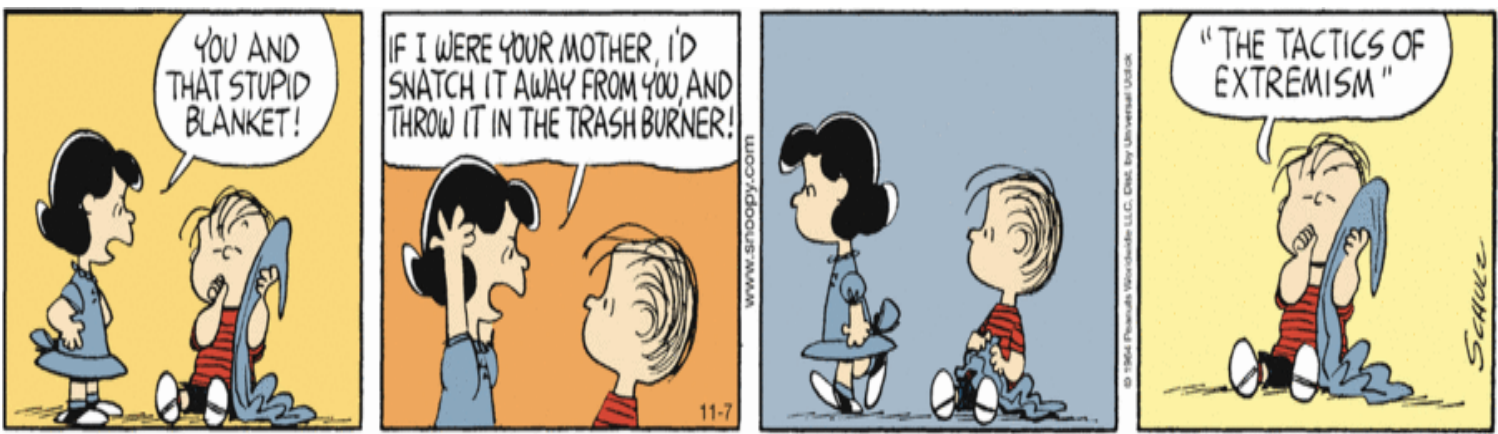

Figure 11 Comic 8

Retrieved on July, 07, 2011 
In the conversation above Lucy looked so annoyed when she looked at Linus who was embracing his blanket. Lucy thought that it was a bad habit and he should get rid of it. She scolded Linus as he could not get rid of his blanket. As Lucy became so irritated she said that if she were his mother, she would grab the blanket and throw it into a trash burner. Linus who did not like the way his sister scolded him and felt helpless just said "The tactics of extremism". Linus statement implied that he did not like the rude behaviour of her sister.

\section{Comic 9}
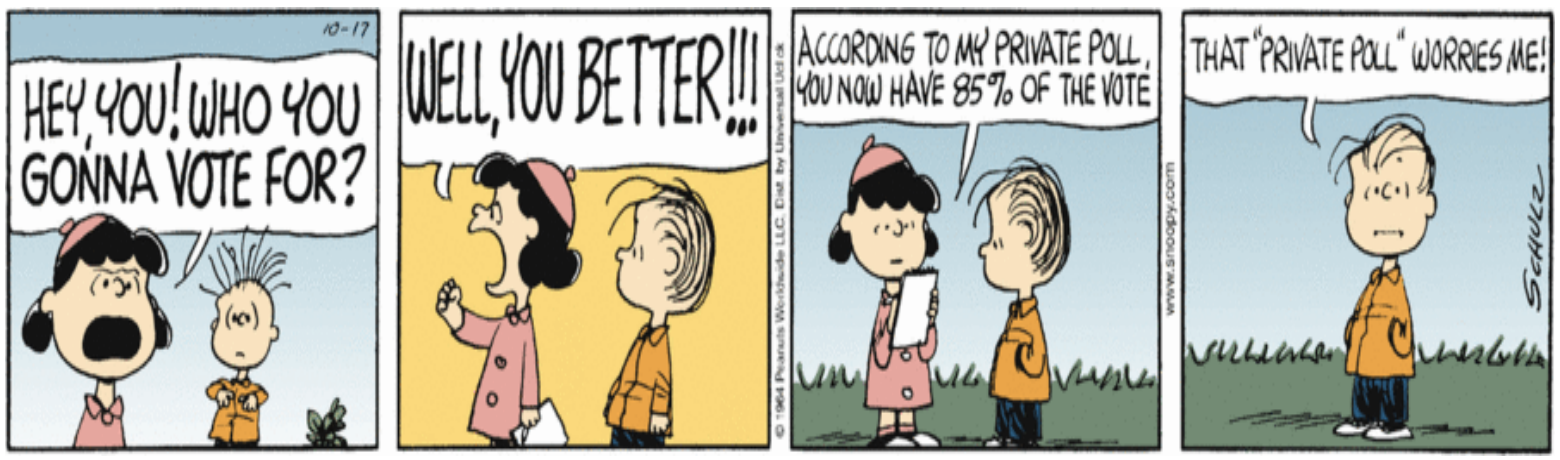

Figure 12 Comic 9

Retrieved on October 17, 2011

Lucy asked by yelling out to someone who was going to cast his vote for a student presidential election. Asking or shouting to someone impolitely was not acceptable manner in a democratic election process. That was the way Lucy conducted her private poll for her brother Linus. Then, she was showing the poll's result to Linus, it showed that Linus was temporarily leading. According to Lucy he gained $85 \%$ for the vote. Although Linus was still leading but he felt worried with what Lucy did in the poll. Lucy's action could be considered illegal.

\section{Comic 10}
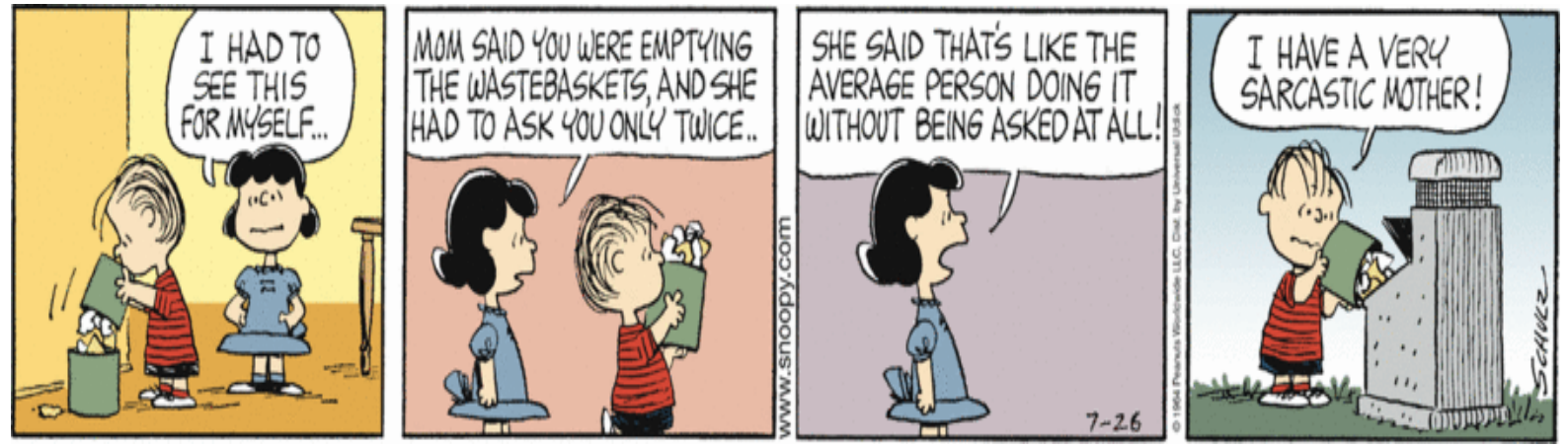

Figure 13 Comic 10

Retrieved on July 16, 2011

Lucy was keeping eyes on Linus when he emptied a trash. While He was emptying the trash, Lucy told Linus what her mother said to him. Lucy said that their mom had asked Linus twice to empty the trash before he did it. Lucy added that their mom said that average person would do it without being asked. Being irritated with what Lucy had said Linus replied "I have a very sarcastic mother!” Linus's reply implied that he did not like what his mother's said to him. 


\section{Comic 11}

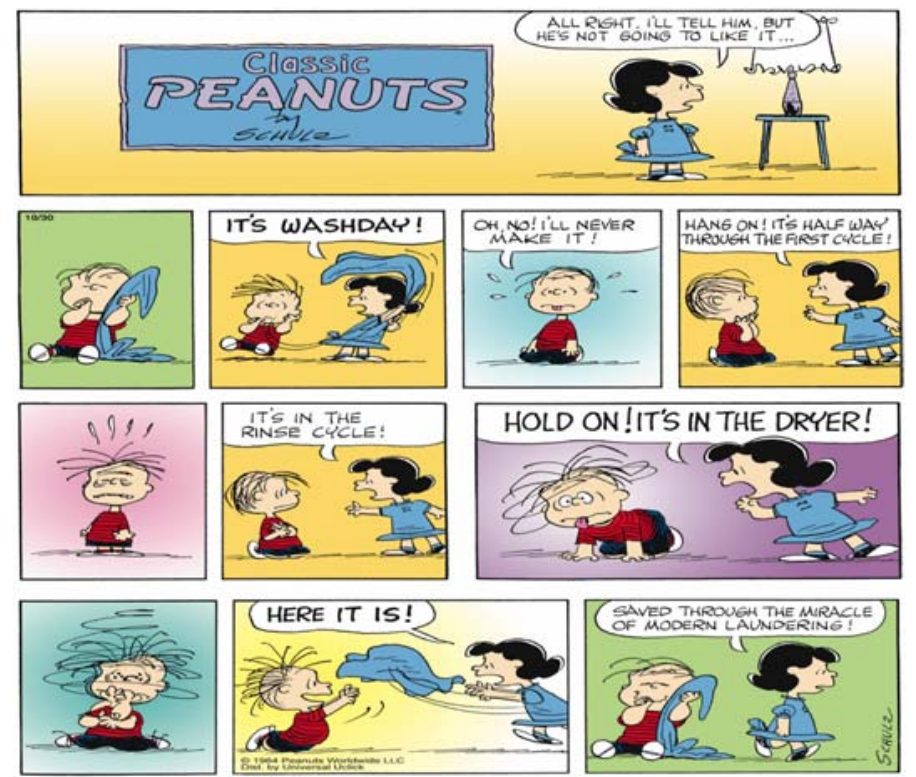

Figure 14 Comic 11

Retrieved on October 30, 2011

The conversation above showed that Lucy would like to wash Linus's blanket with a washing machine. She directly grabbed the blanket from Linus, and off course he did not like it for two reasons. Firstly, he did not like the way Lucy snatched his blanket, as it was too rough for him. Secondly, he was worried if he would lose his blanket and would never get it back again. While Linus was worried and crying for his snatched blanket, Lucy tried to calm him down by saying it would not take a long time to wash and dry the blanket with the washing machine. Finally Linus felt relieved and happy when Lucy threw the blanket that had been washed and dried while she was saying "save through the miracle of modern laundering", it implied that he just had been saved by the washing machine and he was very lucky.

\section{Comic 12}
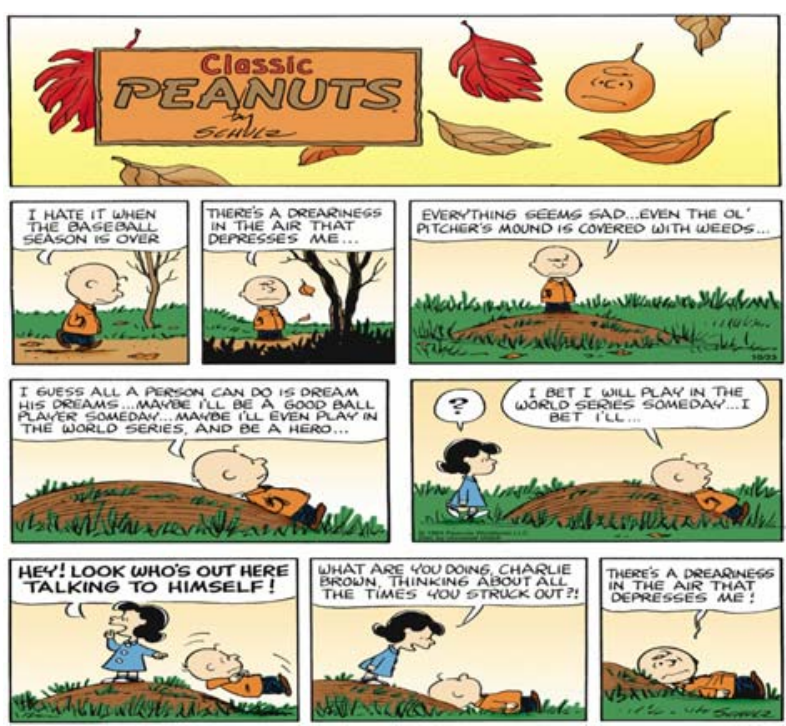

Figure 15 Comic 12

Retrieved on October 23, 2011 
Charlie brown was a fanatical admirer of baseball game season, and he looked very sad and disappointed when the season was over. He even felt hopeless and unmotivated with the end of baseball game season. He looked more pathetic when he saw the baseball field ground and the pitcher mound were fully covered by weeds and that was the miserable sight. He was lying down on the pitcher mound while He kept talking to himself and imagining about people who might dream of him. Charlie said that people might dream that he, someday, would become a great baseball player. What Charlie was saying about people was definitely on the contrary with the fact. Charlie even also dreamed of himself to become a great baseball player ever in the world. Then, while Charlie was daydreaming, Lucy came to him, but he did not realize it. Lucy, then, shouted to someone by saying there was somebody here who was talking to himself. Being surprised with Lucy's loud shout, Charlie looked upwards and saw Lucy's face, and he said "There's a dearness in the air that depresses me". Charlie statement implied that he felt annoyed and did not like Lucy's sudden appearance that ruined his day-dreaming.

\section{Comic 13}
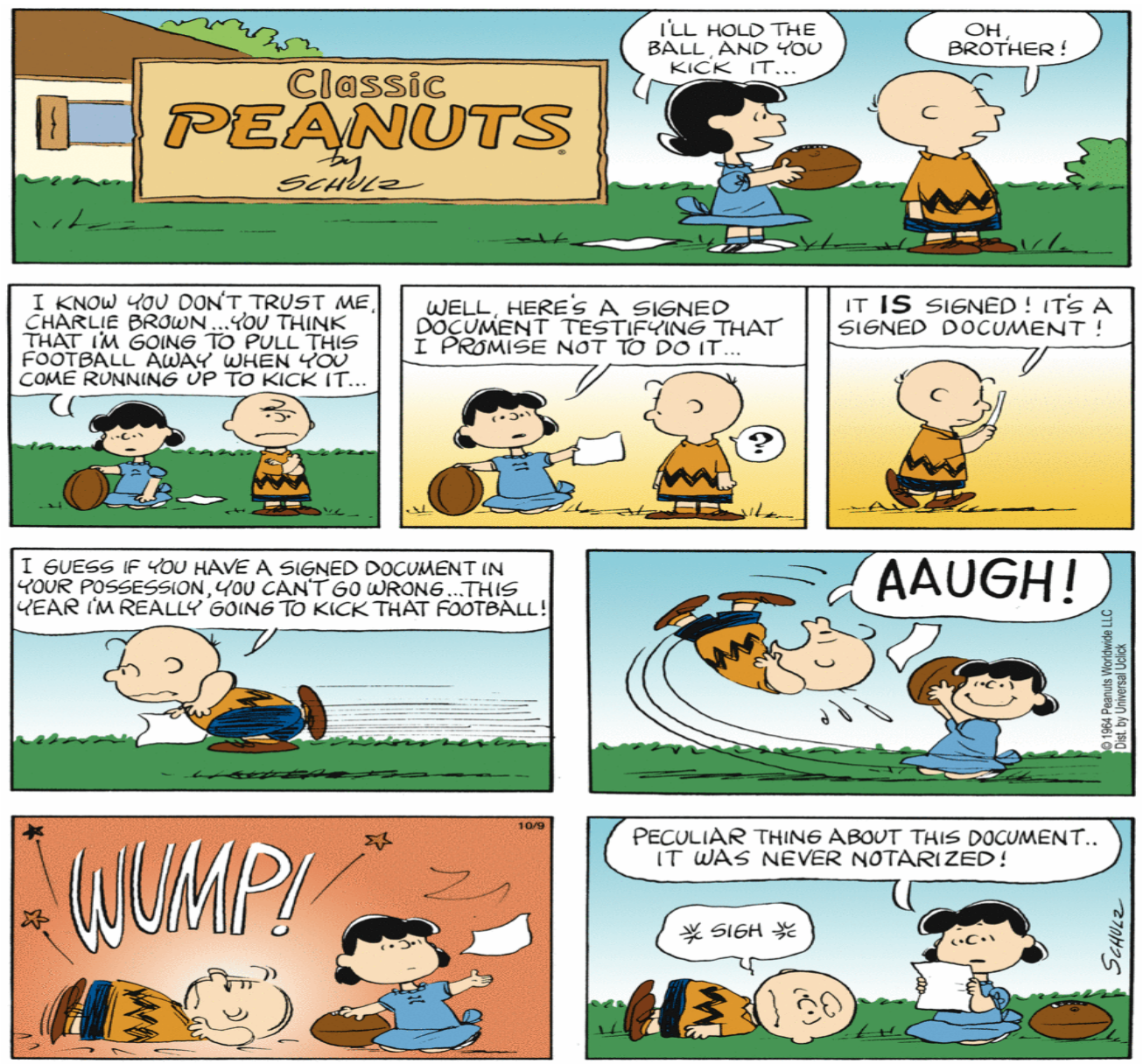

Figure 16 Comic 13

Retrieved on October 9, 2011

Lucy offered a ball to Charlie to kick it, but he did not care about it. Charlie responded her offer by showing his unwillingness. Because he had an experience about this, he had tried to kick the ball, but Lucy swung the ball and he felled down. Having received cold response, Lucy assured Charlie that this time she would not do the same thing as what she had done before to him. Lucy showed a letter which had been signed. Then, Charlie grabbed the letter. He read the letter, felt 
convinced that Lucy would keep her promise. He, then, ran directly towards the ball and tried to kick it, but unpredictably, Lucy swung the ball, and he felled down. Without feeling any guilty of what she had been done to Charlie, Lucy said "Peculiar thing about this document, it was never notarized". Lucy statement implied that the letter was not legally binding as it was not signed by a notary. Lucy's action was, off course, not acceptable and Charlie who felt cheated just groaned by saying "sigh".

\section{Maxim Violating}

According to Grice Maxim violating is when the speakers intentionally generate a misleading implicature or when they break maxim, they will be liable to mislead. In other words, the speakers say something which leads the hearers to get wrong assumption of what the speakers have said. It also happens when a speaker does not want the hearer to know his/her intention, the speaker does not want the hearer to know what the truth and he or she just want the hearer understands of his or her utterances.

\section{Violating Quantity}

It is unostentatious violation of maxim which generates the intentionally misleading implicature. When a speaker gives less information, it leads the hearer to get wrong misleading assumption, as it can be seen in the conversation at below:

\section{Comic 14}
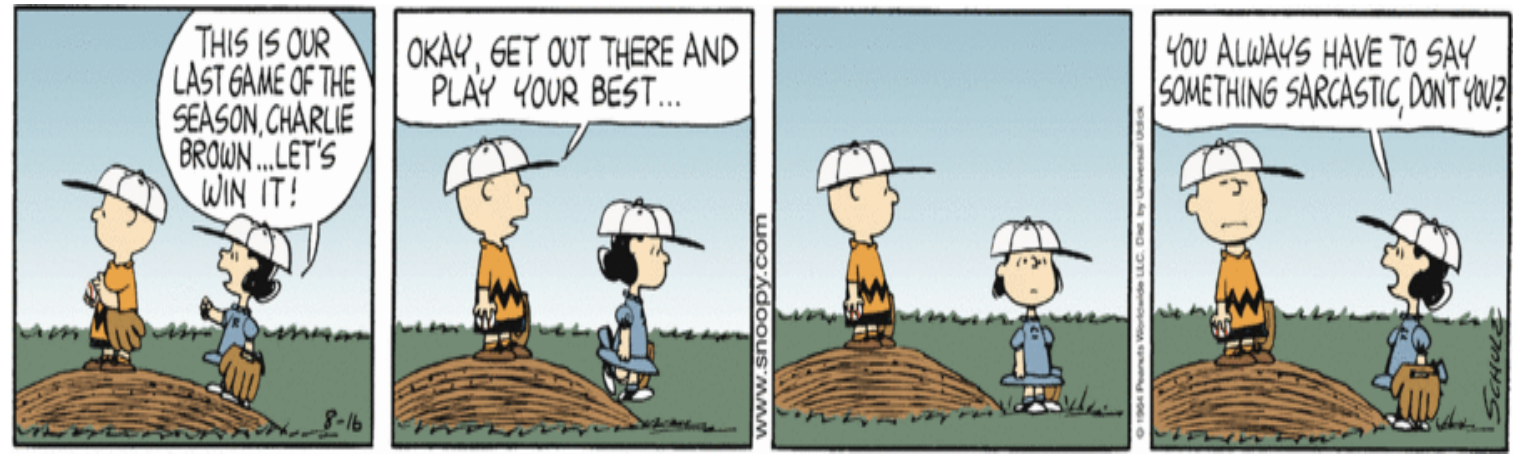

Figure 17 Comic 14

Retrieved on August 16, 2011

Lucy told or reminded Charlie that it was their last game of this season. Lucy did not want to lose and missed this game. She hoped that Charlie could play well and won the game, and then Charlie said Okay. Charlie also encouraged and told Lucy to play her best. By saying "Okay, get out there and play your best". Lucy felt that Charlie doubted her ability to play her best for the team. She felt offended with what Charlie had said. She also felt as if she was only a weak girl who could not play her best. She obviously did not like Charlie's remark. Then, Lucy expressed her emotion to Charlie by saying "you always have to say something sarcastic, don't you?". Charlie looked stunned and speechless as his effort to give more fighting spirit during the game was misunderstood by Lucy.

\section{The Analysis Results}

Based on, the analysis of the dialogues in the 14 comic strips above, the writers found Maxim flouting and maxim violating and from all the strips which generate conversational implicature. The data presented in the table below show that flouting maxim of manner has the highest occurrences which took place in 6 comic strips or $43 \%$ of the data. This kind of maxim flouting is generated in the 
two dialogues between Charlie Brown and Lucy van Pelt and the other four dialogues are made by Lucy van pelt and Linus van Pelt.

Then, flouting maxim of quantity is in the second position with 4 conversational implicature (29\%) in which 3 conversations are generated by Charlie brown and Lucy van pelt and another conversation is generated by Lucy van pelt and Linus van pelt. The third rank is flouting maxim of quality which has 2 conversational implicature (14\%). The two conversations are generated by Lucy van pelt and Linus van pelt. The last one is flouting maxim of relation which has 1 conversational implicature (7\%) generated from the conversation between Charlie brown and Lucy van pelt. Violating maxim of quantity also has 1 conversational implicature (7\%) generated from the conversation between Charlie brown and Lucy van pelt. Both flouting maxim of relation and violating maxim of quantity share the lowest rank in generating conversational implicature. The complete frequency of flouting maxim and violating maxim can be seen in the table below:

Table 1 The frequency and percentage of Flouting maxim and Violating maxim

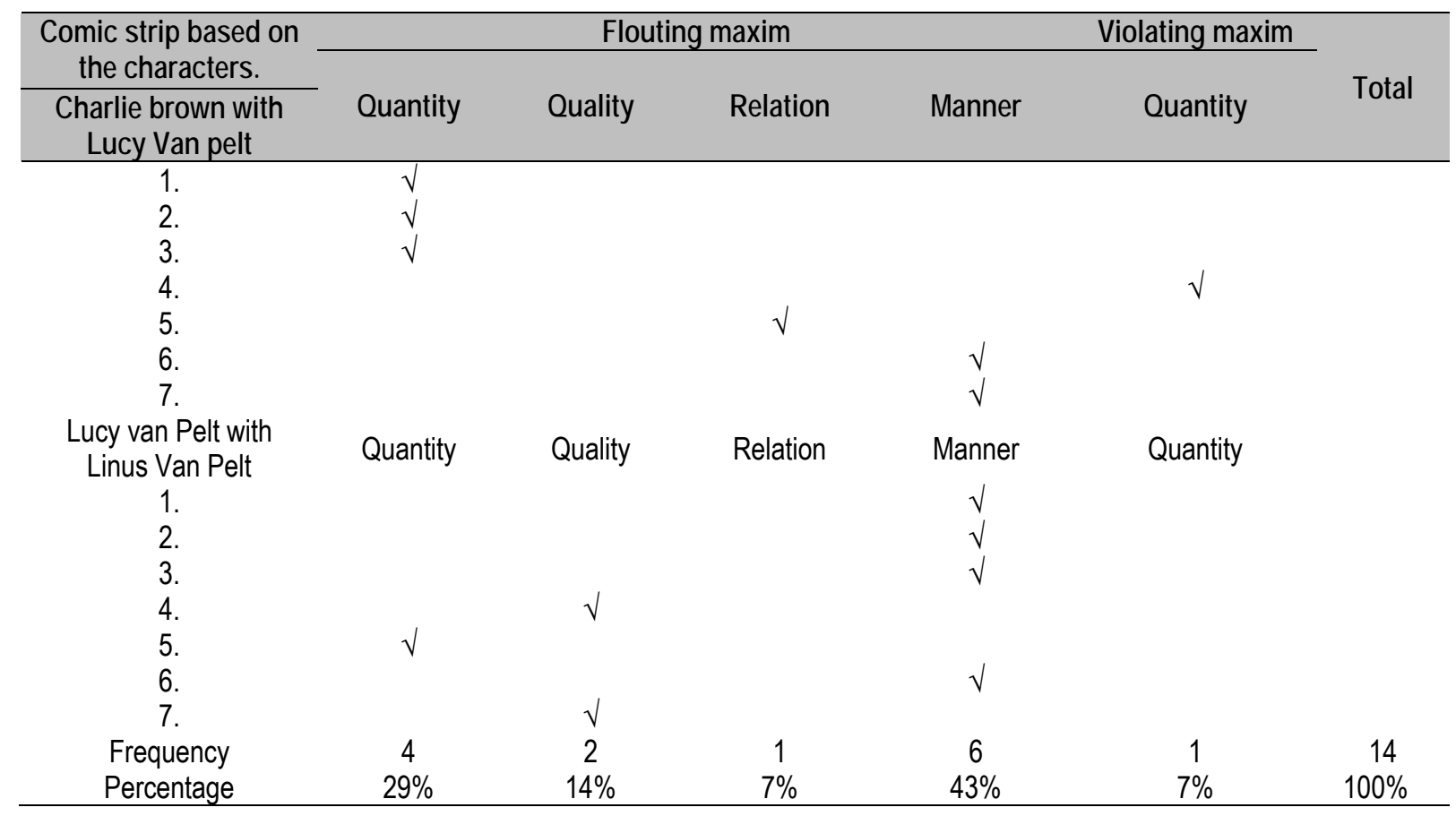

\section{CONCLUSION}

After analyzing the data in the previous section, it is time now for the writers to draw some conclusions. The conclusions are drawn to answer the statement of the problems which has been previously presented in the first chapter. In this chapter, the writers likewise would like to offer some suggestions related to the topic of this research.

Ideally in a conversation or a dialogue, someone can deliver his or her message directly or explicitly so the interlocutor does not find any problem to grasp the message of the speaker. This will happen if the both the speaker and the interlocutor follow the cooperative principles proposed by Grice i.e. being relevant, clear and not ambiguous, enough information given, and being truthful. However, people for some reason break these cooperative principles and go for implied meaning in their conversation which results in conversational implicature. 
Based on the analysis, the writers conclude that all 14 Peanuts comic strips generate conversational implicature. This happens because the main characters in these comic strips namely, Charlie Brown, Lucy van Pelt, and Linus van Pelt often convey their messages implicitly during the conversation or dialogues. As the conversational implicature is the result of maxim flouting, the writers found that the four maxim flouting exist in the analyzed data they are maxim flouting of quantity, quality, manner, and relation. In terms the frequency of occurrence, the writers concludes that the highest occurrence is flouting maxim of manner which accounts for $43 \%$ in which $14 \%$ are the dialogues between Charlie Brown and Lucy van Pelt, and the remaining 29\% are the conversations between Lucy van Pelt and Linus van Pelt. The second is flouting maxim of quantity which takes place in 4 dialogues (29\%) in which 3 (21\%) are conversations between Charlie brown and Lucy van pelt, 1 is the conversation between Lucy van pelt and Linus van pelt. The third is flouting maxim of quality which consists of 2 conversations between Lucy van pelt and Linus van pelt. The fourth is the least occurrence which is occupied by flouting maxim of relation and violating maxim of quantity each of them only has 1 conversational implicature.

Furthermore, the writers conclude that each character has his/ her own ways to convey his or her message to the hearer by breaking rules of maxim. The speaker does it for some reason which makes the hearer thinks or guesses beyond what has actually been said. Likewise, the writers also conclude that the speakers intentionally break the maxim in each story to generate humorous effect that will make the story more amusing and interesting.

Conversational implicature may happen in our daily life, and in this scientific paper the writers only focuses on the existence of conversational implicatare and its frequency of occurance. The writers, therefore, suggest that a more thorough study may be conducted to investigate the psychological reasons for breaking cooperative princinples, maxim flouting and maxim violating in daily conversation.

\section{REFERENCES}

Browm, Keith; V, Eve; McMahon, April; Miller, Jim; Milroy, Lesley. Pragmatic. In Oxford Textbooks in Linguistic, Series editors.

Cruse, A. (2004). Meaning in Language. In An introduction to Semanctic and Pragmatics, Second Edition (pp. 363-373). New York: Oxford Uniiversity Press Inc.

Cutting, J. (2008). Pragmatics and Discourse, Second edition. USA and Canada: Routledge.

Jaszczolt, K. M. (2002). Semantic and Pragmatic. Great Britain: Pearson Education.

Mey, J. L. (2001). Pragmatic. In an introduction, Second Editon (pp. 71-88). Australia: Blackwell Publishing.

Peanuts Characters . (n.d.). Retrieved November sunday, 2011, from Peanuts : www.peanuts.com/characters

Peanuts Characters. (n.d.). Retrieved 12 4, 2011, from Peanuts: www.peanuts.com/characters

Peanuts comic strips. (n.d.). Retrieved July-October 1-31, 2011, from gocomics: www.gocomics.com/peanuts 
Peanuts. (n.d.). Retrieved September-October Thursday, 2011, from gocomics: www.gocomics.com/peanuts

Thomas, J. (1995). Meaning in interaction. In an introduction to Pragmatic (pp. 1-2 , 55-77). London: Longman Group Limited.

Yule, G. (1996). Pragmatic. New York: Oxford University Press. 